\title{
Contextualizing Speed and Cross-border Acquisition Performance: Labor Market Flexibility and Efficiency Effects
}

While cross-border acquisitions have become common, our knowledge and understanding of this phenomenon remains fragmented (Shimizu, Hitt, Vaidyanath, \& Pisano, 2004; Weber \& Fried, 2011). As the value and the volume of international transactions continue to grow (Cartwright, 2005; Lakshman, 2011), most cross-border acquisitions are not successful (Shimizu et al., 2004). In general, acquisition success rates remain low with failure rates ranging from 40 to as high as 90 percent (Bagchi \& Rao, 1992; Christensen at al., 2011; Homburg \& Bucerius, 2006). Additionally, despite decades of research (Haspeslagh \& Jemison, 1991; Birkinshaw, Bresman, \& Hakanson, 2000; Bauer \& Matzler, 2014), a metaanalysis has found the most common acquisition research variables have no consistent and significant effects in explaining acquisition performance (King, Dalton, Daily \& Covin, 2004). As a result, the mechanisms influencing value destruction or creation remain unclear (Ellis, Reus, \& Lamont, 2009), and represent a puzzle for both academics and practitioners (Meglio \& Risberg, 2010; Weber, Tarba, \& Bachar, 2011). For cross-border acquisitions, Wu and colleagues (2016) suggest theory does not fully predict the impact of host country institutions on internationalization performance, because the institutional environments of host and parent firms interact.

An interaction between combining firms and their different institutional environments points to the importance of integration on acquisition performance (e.g., Angwin, 2004; Angwin \& Maedows, 2015; Appelbaum, Gandell, Yortis, Proper, \& Jobin, 2000; Homburg \& Bucerius, 2006; Schlaepfer, et al., 2008; Weber \& Tarba, 2013), including integration speed (Bauer, King, \& Matzler, 2016; Meglio, King, \& Risberg, 2015, 2017). This reflects the recognition that "all value creation takes place in post-merger integration" (Haspeslagh \& Jemison, 1991, p. 132). In this paper, we follow Larsson and Finkelstein's (1999, p. 6) conceptualization of integration as "the degree of interaction and coordination between the 
two firms involved in a merger or acquisition". In addition to determining integration depth, or the amount of coordination (Steigenberger, 2016), managers confront integration planning and its execution (Jemison \& Sitkin, 1986). While integration levels are often largely dictated by strategic fit (Capron, Dussauge \& Mitchell, 1998), managers have discretion on speed of integration (Homburg \& Bucerius, 2005, 2006; Bauer \& Matzler, 2014). Integrating too slow risks not realizing benefits (Cording et al., 2008). At the same time, integrating too fast risks socio-cultural turmoil, including: resistance, in-group and out-group biases, and loss of key employees (Meglio, King \& Risberg, 2015; Puranam, Singh \& Chaudhuri, 2009; Paruchuri, Nerkar \& Hambrick, 2006; Weber, Tarba \& Reichel, 2009).

Research examining integration speed in acquisitions tends to focus on the firm level and examines the relationship of speed of integration and acquisition performance (e.g. Angwin, 2004; Homburg \& Bucerius, 2006; Bauer, King \& Matzler, 2016; Uzelac, Bauer, Matzler \& Waschak, 2016) or internal reorganization (Cording, Christman \& King, 2008). While research has examined cultural differences in cross-border acquisitions, there is less research on institutional differences (Alimov, 2015; Chacar et al., 2010; Choi et al., 2016) and little to no research has examined the impact of institutional differences on integration speed. An exception involves recent research on integration approaches from emerging economies. For example, Liu and Woywode (2013) find Chinese acquirers of companies in German speaking countries apply a light integration approach which confirmed earlier results that Asian acquirers tend to integrate acquisitions slowly (Cogman \& Tan, 2010). Consequently, research continues to call for examining the impact of different institutional contexts in crossborder acquisitions (Buckley et al., 2016; Meyer et al., 2009; Xing, Liu, Tarba \& Cooper, 2016; Zheng, Wei, Zhang \& Yang, 2016).

A country's institutional environment reflects "the set of all relevant institutions that have been established over time" (Kostova \& Roth, 2002, p. 180), or the "rules of the game" (North, 1990). Research suggests that country effects on firm performance can be as powerful 
as industry effects (Makino, Isobe, \& Chan, 2004), making the examination of institutional contexts an important line of inquiry in cross-border acquisition research (Ferreira, Santos, de Almeida \& Reis, 2014; Stucchi, 2012). For example, institutional differences across countries influence entry mode decisions (Meschi et al., 2016; Slangen \& Tulder, 2009; Meyer et al., 2009), and innovation performance (Wu et al., 2016). Beyond traditional differences in country institutions, research in economics suggests that labor factor market conditions (Botero et al., 2004; Siegel \& Larson, 2009), including labor protections preventing dismissal of workers, influences a country's employment (Breen, 2005; Neumark \& Wascher, 2005). Factor conditions reflect "formal and informal rules governing the labor market" (Siegel \& Larson, 2009, p. 1527). This makes labor market factor conditions relevant to cross-border acquisitions, as a consistent motive behind acquisitions is to improve efficiency from reducing personnel. For example, country contexts that provide greater employee protection may decrease the fear and uncertainty of employees following an acquisition (Homburg \& Bucerius, 2006), and different labor market factor conditions can drive higher transactions costs (e.g., Hoskisson et al., 2012).

In our study, we make multiple contributions to theory by developing and testing the impact of the labor market factor conditions on integration processes. First, our study answers calls to examine the business environment surrounding acquisitions (Teerikangas \& Joseph, 2012; King \& Schriber, 2016) and across different institutional settings (Paustian-Underdahl et al., 2017). With the notable exception of Capron and Guillén (2009), the impact of labor market conditions on integration decisions and acquisition performance remains largely unexamined in developed economies, and we find labor market differences matter for acquisition outcomes. Second, we address one of the most important managerial choices in acquisitions, that of integration speed (Bauer \& Matzler, 2014). We develop how the institutional characteristics moderate central relationships in acquisition research and can resolve conflicting results in integration research. In our examination of the institutional 
effects of labor market flexibility and efficiency, we find that they do not have direct effects on acquisition performance. Instead, labor market factor conditions moderate the relationship of human and functional integration speed on acquisition performance. This underscores the need for managers and researchers to consider how elements of an institutional environment change established experience or anticipated relationships. Third, our study contributes to new institutional economics research on acquisitions. While this research field has pointed to discrepancies in the institutional setting in acquisitions involving developing and developed countries (e.g. Lebedev et al., 2015), our research begins to outline how institutions offer a fruitful starting point for understanding acquisition performance also in acquisitions involving developed countries.

\section{THEORY AND HYPOTHESES DEVELOPMENT}

New institutional economics (NIE) examines the role of institutions in developed economies on economic growth (Faundez, 2016). As defined by Douglas North, an architect of NIE, institutions are the "rules of the game" in society that constrain human interaction (North, 1990). For cross-border acquisitions, the "rules" in one society often differ from another, and manager decisions are constrained by the institutional environment (Meyer \& Peng, 2016). However, acquisition research has focused more on issues internal to combining firms, in spite of observations that integration decisions are not always "the buying companies' free choice" (Bauer, 2016, p. 343). For example, managers have limited choice on the environmental or tax regulations applying to an acquisition. Additionally, firms also contend with variance in labor laws. Specifically, firms conducting cross-border acquisitions can struggle to realize cost efficiencies in countries with strong employment protection laws (Belenzon \& Tsolmon, 2016). For example, some integration efforts generally accepted in one culture may contradict basic cultural assumptions in another (e.g. Cooke \& Huang, 2011). This is also consistent with calls to consider additional aspects of national institutional differences (Stenard \& Sauermann, 2016). 
The impact of different labor market characteristics on the pace of integration needs examination, as the labor market influences the ability of an acquirer to implement changes in personnel (Schneper \& Guillén, 2004). The importance of the institutional context derives from the fact that it sets the frame for integration processes and outcomes (Alimov, 2015), and employee participation differs between legal environments to impact what can be achieved during integration (Aguilera \& Dencker, 2004). Legal regulations set boundaries, even though multinational firms develop capabilities in dealing with institutions that are transferable (Carney et al., 2016). Limited transferability from institutions and capabilities displaying path dependency (e.g., Faundez, 2016) likely has an impact on choices for the speed of integration in cross-border acquisitions.

Theory identifies speed of integration as central to acquisition outcomes. However, research provides conflicting results regarding the relationship between integration speed and acquisition performance. On the one hand, slower integration can foster trust building and on the other hand faster integration can minimize instability and enable realizing improvements faster (Angwin, 2004; Buono \& Bowditch, 2003; Birkinshaw, Bresman, \& Hakanson, 2000). We anticipate beginning to reconcile these divergent expectations is aided by separately examining human and functional integration speed. These separate constructs relate to different decisions that often involve trade-offs where progress on one dimension can come at the expense of the other (Haspeslagh \& Jemison, 1991). Further, adjusting speed of human and task integration separately has been found to positively influence acquisition performance (Bauer, King, \& Matzler, 2016; Birkinshaw et al., 2000; Schweizer, 2005; Gates \& Very, 2003). The combined implication from acquisition research is that managing integration and its speed is an important, but an insufficient condition for improving acquisition performance. Further improvement in performance and our understanding of its antecedents likely also needs to consider differences in the institutional context. Each of these concepts and their interactions are developed in the following subsections. 


\section{Human Integration Speed}

Employees balance commitment to an organization with an organization's observed commitment to people (Ahammad, Glaister, Weber \& Tarba, 2012), and human integration provides evidence of an acquiring firm's commitment to employees. Human integration involves processes aimed at reducing uncertainty and establishing mutual understanding and trust between employees of combining organizations, as well as a shared identity in a new organization (Birkinshaw et al., 2000). During an acquisition, employees face unclear job prospects, increased workload, changes in work processes, reporting relationships and status, and role ambiguity driving a need to communicate with employees (Ullrich \& van Dick, 2007). These concerns relate to research consistently showing human integration is important to acquisition performance, as human integration enhances willingness to share knowledge, interact, and cooperate with employees from the other firm (Larsson \& Finkelstein, 1999).

Research has also begun to consider the speed of human and functional integration in improving acquisition performance. Early human integration, involving efforts to learn about the other firm's culture, can lead to more benevolent attitudes that are associated with synergy realization (Schweiger \& Goulet, 2005). Additionally, efforts to integrate cultures can mitigate negative influences from cultural differences (Teerikangas \& Very, 2006). Quicker human integration also minimizes instability in the organization (Angwin, 2004) and helps managers maintain integration momentum (Graebner, 2004; Gates \& Very, 2003). Therefore, we propose:

Hypothesis 1a: Higher human integration speed is associated with higher acquisition performance.

Still, there are arguments for high human integration speed resulting in negative acquisition performance. Fast human integration can counteract intentions of creating a mutual learning environment for the employees of both entities (Buono \& Bowditch, 2003). This may have greater importance in cross-border acquisitions where trust building requires 
time to set a foundation for success (Bijlsma-Frankeema, 2004; Liu, \& Woywode, 2013; Schweiger \& Goulet, 2005). As a result, fast human integration may also be detrimental for increased acquisition performance. For example, slow integration requires less effort of employees (Homburg \& Bucerius, 2006), and it can mitigate communication problems that are common during cross-border acquisitions (Lee et al., 2014). Consequently, we offer a competing hypothesis that:

Hypothesis 1b: Higher human integration speed is associated with lower acquisition performance.

\section{Functional Integration Speed}

While integration of functional areas can be a source for coordination problems, conflicts and organizational resistance (Cooke, 2006; Shrivastava, 1986), its aim is minimizing coordination problems and creating operational synergies. There are strong arguments for rapid functional integration based on realizing the benefits of an acquisition sooner (Sirower, 1997). Faster integration is associated with quicker returns on investment, greater effects of early actions, and the faster combination of resources (Angwin, 2004; Homburg \& Bucerius, 2006; Morag \& Barakonyi, 2009). For example, even a one-month delay in realizing cost savings can significantly reduce the net present value of an acquisition (Chanmugan, et al., 2005). Therefore, we propose:

Hypothesis 2a: Higher functional integration speed is associated with higher acquisition performance.

Meanwhile, there are also strong arguments in favor of more deliberate functional integration. For example, coordination inevitably involves direct costs to achieve interoperability, modify organizational interfaces, and train employees on updated processes and responsibilities. While such costs likely occur regardless of integration speed, integrating faster is consistent with employee learning and adjustment can lead to organizational breakdowns and higher employee turnover (Hambrick \& Cannella, 1993). Further, the introduction and distribution of new responsibilities in an organization takes time 
(Birkinshaw, Bresman, \& Hakanson, 2000). As a result, fast functional integration increases the risk of insufficient preparation that contributes to misunderstanding. For example, functional integration disrupts established processes and routines (Paruchuri, Nerkar \& Hambrick, 2006; Vester, 2002) and this can lead to employee resistance and lower performance (Cooke \& Huang, 2011; Larsson \& Finkelstein, 1999). Faster integration also limits understanding tacit target processes (Schweizer \& Patzelt, 2012; Weber, Shenkar \& Raveh, 1996). For example, faster integration leaves less time to understand what processes can be modified without driving knowledge transfer losses (Puranam, Singh \& Chaudhuri, 2009). Therefore, we propose:

Hypothesis 2b: Higher functional integration speed is associated with lower acquisition performance.

\section{Labor Market Factor Conditions}

The institutional environment likely modifies integration decisions in cross-border acquisitions (Ang, Benischke, \& Doh, 2015; Capron \& Guillén, 2009; Collings, Scullion \& Morley, 2007; Mellahi \& Collings, 2009; Zhu, Xia, \& Makino, 2015). To account for contextual differences, research has investigated effects of institutional distance between the host and the target country (Hitt et al., 2004) to find that institutional distance influences the likelihood of acquisition completion (Dikova, Sahib, \& van Witteloostuijn, 2010) and subsequent success (Zhu, Xia, \& Makino, 2015). While research recognizes the legal framework of employee protections influences personnel decisions or limits the actions of managers can make following an acquisition (Khan, Soundararajan, Wood, \& Ahammad, 2017; Siegel \& Larsson, 2009), research has not examined the impact of different labor market factor conditions.

In considering labor market factor conditions, we focus on the flexibility and efficiency of labor markets that are critical to allocating workers effectively and providing incentives for employees to give their best effort (Chacar, et al., 2010). At the national level, 
lower unemployment relies on flexibility, or the ability of labor markets to shift workers from one economic activity to another rapidly and at low cost (Mortensen \& Pissarides, 1994). In turn, efficient labor markets provide clear incentives for employees, and promote meritocracy and diversity in the workplace (Greig, 2008). The combined effect of labor market flexibility and efficiency can make a country more attractive to businesses or trigger acquisition activity (Alimov, 2015), particularly cross-border acquisitions that facilitate the redistribution of workers and entering new markets. Next, we separately develop contingent impacts of labor flexibility and efficiency on the relationship between acquisition integration and performance.

Labor market flexibility. Integrating firms following an acquisition generally involves the elimination of redundant resources, including jobs and employees (DiPrete, 1993). In some acquisitions, the main purpose is to reduce the overall workforce to lower costs, making employee termination an integral part of the value creation (Siegel \& Simons, 2010). Still, the institutional environment of a target firm influences implementation of acquisition integration and capable acquirers consider this in advance. For example, Teva Pharmaceutical Industries delayed an acquisition of a Hungarian firm for five years over the acceptance of lay-offs (Brueller et al., 2016). Greater labor market flexibility reduces efforts and costs for acquirers to change workforce, facilitates introducing non-permanent labor contracts and a greater freedom in firm operations (Anner \& Caraway, 2010). For countries with tightly regulated labor markets, employee turnover is more difficult and this can lower acquisition performance (Debroux, 1996) due to higher costs than markets with labor market flexibility that allow more rapid employment changes (Anner \& Caraway, 2010).

For human integration, we anticipate high labor market flexibility will positively moderate its impact on acquisition performance as cross-border acquisitions in more flexible labor market environments allow capturing more value potential (Alimov, 2015). In flexible labor markets, employees are adept at making adaptions that can facilitate performing acquisition integration quickly. For example, research consistently supports strategic 
flexibility being related to higher performance (Brozovic, 2016). This relates to workers in flexible contexts being more open to performing different tasks (Sarala, Junni, Cooper \& Tarba, 2016). Still, workers often make specific investments in firms to learn work processes that have limited value in other firms (Piketty, 2014), and this can contribute to worker commitment to an organization despite changes. Therefore, we propose:

Hypothesis 3a: Labor market flexibility positively moderates the path from human integration on acquisition performance.

For functional integration, flexibility can hurt coordination from increased variance in employee behavior that reduces interoperability (Sarala, Junni, Cooper \& Tarba, 2016). For example, organizational knowledge is embedded in routines that are disrupted by acquisitions (Paruchuri et al., 2006). Labor market flexibility may also drive undesired employee turnover from employees leaving an organization, and high employee turnover following an acquisition negatively impacts acquisition outcomes (Eckardt, Skaggs \& Youndt, 2014; Walsh, 1988). To compound problems from employee turnover, managers often overestimate workforce reductions possible after an acquisition (Krishnan, Hitt \& Park, 2007), contributing to the inadvertent destruction of sought capabilities (Lord \& Ranft, 2000). Therefore, we propose:

Hypothesis 3b: Labor market flexibility negatively moderates the path from functional integration speed on acquisition performance.

Labor market efficiency. An efficient labor market is characterized by property rights, free markets, and competition (Piketty, 2014), and this provides performance incentives and upward mobility. This results in higher productivity, because the best talent is attracted and retained. For example, performance-related pay has been found to improve labor market flexibility (Laezar, 1999). Consequently, labor market efficiency influences human resource management (Mellahi \& Collings, 2009). The transfer of employee skills across industries explains both labor flows and corporate diversification (Neffke \& Henning, 2013), or it 
provides insight into possible cross-border acquisitions motives (Lebedev et al., 2015). For example, acquisitions can provide a method of gaining needed employees and skills (Mayer \& Kenney, 2004).

For markets with higher labor market efficiency, or developed employee incentive and advancement systems (Greig, 2008), we anticipate access and transferability of employees and needed skills will be higher. This suggests that labor market efficiency will have beneficial effects on both human and functional integration speed. This relates to employees in efficient labor markets being more open to change due to perceptions of greater overall opportunity. When markets lack labor market efficiency (e.g. in transparency of competences), there will be less opportunity. For example, Cooke (2006) concludes foreign direct investment into mainland China is difficult due to low transparency. Therefore, we propose:

Hypothesis 4a: Labor market efficiency negatively moderates the relation of human integration speed and acquisition performance.

Hypothesis 4b: Labor market efficiency positively moderates the relation of functional integration speed and acquisition performance.

\section{METHODOLOGY}

\section{Sample}

For testing our proposed hypotheses, we used a multi-method design combining two data sources. First, a survey investigated organizational variables. Primary data provided greater detail for investigating acquisition integration than is available from secondary data (Zaheer et al., 2013). Second, we used secondary data to assess the labor market factor conditions. This enabled complementing key-informant information most knowledgeable about strategic and organizational issues (Ellis et al., 2009) with archival information on national labor market differences. It also has advantages in avoiding common method bias and allowing us to lag the measurement of constructs. 
The survey was conducted in early 2016. Our survey instrument was developed in early 2016 and tested by a two-step pretest conducted with practitioners and academics with acquisition experience in February (Churchill, 1995). For the structure and the design, we followed the advices of Dillman et al. (Dillman, 2000; Dillman, Smyth, \& Christian, 2009). Based on the results of the pretest, we made minor modifications. To improve clarity, we added some examples to specific items and reformulated two questions to improve readability. In late February, we sent out the questionnaires together with a personalized cover letter, an executive summary of the last year's study, and a separate sheet, where respondents could add their contact details in case they were interested in the results of the study at hand. Key executives from the acquiring firms were selected as respondents because they tend to be most knowledgeable about the requested issues (Datta, 1991; Homburg \& Bucerius, 2006). We would have preferred to interview executives from acquiring and target firms, but managerial turnover precluded including target executives. After sending out the questionnaires via mail, we started with follow-up phone calls two weeks later. In sum, we gathered 203 completed questionnaires from CEO's, CFO's or other top managers, where 107 were returned from the German-speaking countries, 96 from Scandinavian countries and two others. Our response rate (about 12\%) is due to the length of our survey instrument and the requested issues sufficient and in line with other acquisition research (Homburg \& Bucerius, 2005).

For sample construction, we implemented temporal, regional, industry, and firm size restrictions. We focused on transactions that took place between January 2009 and December 2013 with buyers from the German speaking countries from central Europe (Germany, Austria, Switzerland, and South Tyrol), as well as from the Scandinavian countries. The selection of time period also helps to guarantee that the integration process was already finished or in a final stage (Homburg \& Bucerius, 2005) and to minimize the risks of a potential recollection bias (Ellis, Reus, \& Lamont, 2009; Krishnan et al., 2007). The 
geographical restrictions were driven by four reasons. First, mid-sized firms with a longstanding entrepreneurial tradition and international trading history, play an important role for both regions (for Scandinavia e.g. Holmund, Kock \& Vanyushyn, 2007; for Germanspeaking countries e.g. De Massis, Audretsch, Uhlaner \& Kammerlander, 2017). Second, the countries in these regions can be described as industrial nations where the industries we investigate play a dominant role. Third, the macroeconomic development, an important antecedent for investing abroad (Giovanni, 2005), is comparable across the investigated countries. Finally, Europe, while providing a rather similar institutional setting under the European Union, displays variance in labor market regulations between nations (Botero et al., 2004).

We also focused on more traditional and labor-intense industries (e.g. machinery engineering) with long industry life-cycles for three reasons. First, in labor-intense industries at least some integration is necessary to eliminate redundant resources and to transfer and share resources (Birkinshaw et al., 2000). Second, structural changes require rather stable conditions (Bauer, Dao, Matzler \& Tarba, 2017) and the investigated industries can be described as mature. Third, acquisition motives differ among industries (Teusler, 2008) and restricting industry avoids dilution of examined effects. For example, we deleted private equity as well as financial service or insurance firms. To make a specific acquisition observable, we also limited the acquirer size to 500 million Euros annual sales prior the acquisition. The relevant acquirers from the German-speaking countries and their corresponding acquisitions were identified with the ZEPHYR database from Bureau von Dijk. For the Scandinavian countries, we used a comprehensive database from a consulting firm located in Stockholm. In total, we identified 1737 acquirers that met our sample requirements.

\section{Measures}

For measurement development, we used already tested scales that were modified to fit the context of our study. The major advantages of this approach are: 1) the scales are already 
empirically tested and have proven to be reliable, and 2) it makes our results comparable to other studies.

Acquisition Performance The measurement of performance is a widely-discussed topic in acquisition research (Cording, Christmann, \& Weigelt, 2010; Meglio \& Risberg, 2011). Stock market and accounting based measures have inherent problems (King, Dalton, Daily, \& Covin, 2004), and they are also difficult to compare across different countries (Weetman \& Gray, 1991). Therefore, we used managerial perceptions of performance, and empirical evidence indicates that managerial ratings highly correlate with objective performance measures (Datta, 1991). Acquisition success was assessed with the measurement model developed by Becker (2005), which consists of an objective (Alpha: .811) and a subjective (Alpha: .832) dimension that are each assessed with four items. For measuring performance, both dimensions were aggregated (Alpha: .786). As an indicator for the reliability of our scale, we compared the success and failure rates of our study with those regularly reported. We found no major differences as only $9.4 \%$ of all acquirers display an outstanding performance and this is comparable to Christensen and colleagues (2011). Thus, we conclude that our measure of performance is not biased.

Speed of Integration Speed of integration is usually assessed as duration of integration lasting from deal closing until the desired degree of integration is reached (Cording et al., 2008; Homburg \& Bucerius, 2005; 2006). However, the degree of integration can have an enormous impact on the length of integration, and differences make the comparison across firms of traditional measures of integration speed problematic. For example, an integration time of 12 months could be either slow or fast, depending on the degree of change. If the target is granted autonomy, then 12 months would be rather slow when compared to a firm fully integrating a target in 12 months. To make the firm acquisition integration comparable, we applied a relative measure (Carbonell, Rodriguez-Escudero \& Pujari, 2009) for speed of integration as suggested by Bauer, King and Matzler (2016). Relative approaches are rather 
new in acquisition research, but they are common in new product development literature (e.g., Goktan \& Miles, 2011; Akgün \& Lynn, 2002; Kessler \& Bierly, 2002). We set the duration of integration in relation to the degree of change with the following formula:

\section{Relative speed $=$ Degree of change $/$ Scale points of duration of integration $*$ Duration of}

\section{Integration}

The scales were operationalized with 7 point Likert scales, ranging from $1=$ "no changes at all" to 7 = "major changes" for the degree of change and from $1=$ "longer than 24 months" to 7 = "less than seven months" for the duration of integration. The relative speed scale ranges from 0.143 indicating only minor changes over a period exceeding 24 months after deal closing to 7 , indicating major changes in less than seven months.

Human integration speed was assessed with three items for the degree of change based on the measure developed by Cording and colleagues (Cording, Christman, \& King, 2008). The scale is reliable with Cronbach's Alpha exceeding the recommended threshold of 0.7 (Alpha: .782). The duration of human integration was assessed with a single item. For measuring functional integration, we applied the measure developed by Zaheer and colleagues (2013) with four items. As the duration of integration could significantly vary for different functions, we assessed the duration of integration with the same items as the degree of functional changes. Based on the degree of change and the duration of integration, we compounded the relative measure of speed (Alpha: .722) as suggested by Bauer, King \& Matzler (2016).

Labor Market Flexibility and Efficiency For assessing labor market flexibility and efficiency, we used data from the World Economic Forum’s (WEF) Global Competitiveness Index and compounded the differences of buyer and the target country scores. Consequently, a higher score indicates relatively more flexible or efficient labor markets in the target country compared to the buyer country while a negative value indicates less flexibility or efficiency in the labor market of the target firm. 
Labor market flexibility is assessed by five indicators, namely the cooperation in labor-employer relationships, the flexibility of wage determination, hiring and firing practices, redundancy costs and weeks of salary, and the effect of taxation on incentives to work. The assessment of the efficiency of the labor market consists of five indicators, pay and productivity, reliance on professional management, the countries capacity to retain talents, the countries capacity to attract talents, and the ratio of woman and men in labor force. Both, labor market flexibility and efficiency data were aggregated.

Control Variables We included control variables commonly used in acquisition research. First, relative size strongly affects the acquirers' ability to reorganize a target firm, as smaller targets are easier to absorb compared to larger ones (Cording et al., 2008) and larger targets receive greater managerial attention (Calipha, Tarba, \& Brock, 2010). Second, annual sales indicate acquisition routines in larger firms that can impact the ability to reorganize the target (Barkema \& Schijven, 2008). Third, the number or prior acquisitions is an indicator for acquisition experience, and we asked respondents for the amount of previous acquisitions in the five years prior to focal acquisition identified in the questionnaire. Different types of acquisitions affect the degree of integration and the corresponding managerial measures, as conglomerate acquisitions require less structural managerial integration efforts, leading to our fourth control, transaction type. Fifth, even though the terms merger and acquisitions are often used interchangeably, they are distinct legal concepts and we control for it using a dummy variable, merger acquisition. There is empirical evidence that firm growth strongly impacts organizational behavior (Bauer \& Matzler, 2014; Bauer, Dao, Matzler, \& Tarba, 2017). As a result, our sixth and seventh controls measure industry growth and firm average growth rates. Growth rates were single item measures and aggregated to a mean growth rate before and after an acquisition. The external environment impacts organizations (Kostova, 1999; Lord \& Ranft, 2000; Scott \& Davis, 2007), and acquisitions expose firms to different competitive forces. Competition surrounding acquisitions has recently received increased 
attention (King \& Schriber, 2016; Keil, Laamanen \& McGrath, 2013), so our eighth control measures differences in competition intensity for an acquirer and target country. While prior controls were survey measures, competition intensity was assessed with secondary data from the WEF global competitiveness index. A detailed description of the scales and the psychometric properties can be found in the Appendix.

\section{ANALYSIS AND RESULTS}

\section{Assessing Sample Bias}

To assess potential non-or late response bias, we conducted additional analyses. First, we compared early and late respondents of our sample and found no significant differences. Second, we compared our data at hand with a random sample from the basic population regarding annual sales and relative size (Zaheer, Castaner, \& Sounder, 2013). Again, we find no statistically significant differences between our gathered primary data and the secondary data. Both results indicate that non-or late response bias is not a serious concern for our data (Armstrong \& Overton, 1977).

Additionally, primary data from surveys risks the potential for common method bias for our data (Podsakoff et al., 2012; Podsakoff et al., 2003). Even though some scholars assume common method variance to be an "urban legend" (Spector, 2006), we implemented several measures in our research process to mitigate method variance and conducted some post-hoc tests to identify a potential common method bias problem. First, we guaranteed respondents' anonymity and confidentiality (Podsakoff et al., 2003). Second, we separated the variables in our questionnaire to avoid proximity effects that could affect our data (Podsakoff, 2012). Third, our latent variables were not similar in content. Fourth, all constructs were measured with multiple items (Harrison, et al., 1996). Fifth, labor market efficiency and flexibility were collected from archival data. 
We also conducted Harman's single factor test to get an initial indication of common method bias post-hoc (Podsakoff \& Organ, 1986). The results of an exploratory factor analysis display 8 discrete factors with an Eigenvalue greater than 1, and a single factor only explained 18.67 percent of variance. This result indicates no serious concerns (Podsakoff \& Organ, 1986; Podsakoff, MacKenzie, Lee, \& Podsakoff, 2003). Further, we applied factor analysis to investigate discriminant validity between our constructs (Zaheer et al., 2013). This is important as human and functional integration speed could belong to a greater concept of integration speed, as previous research usually assesses speed of integration with a single item (e.g. Cording et al., 2008). The results of our analysis show two discrete concepts. Together, a priori measures and post-hoc analysis suggest that common method bias is not a serious concern for our data.

\section{Descriptive data}

Table 1 shows the descriptive statistics of our data. The majority of deals involve a target less than half the size of an acquirer (relative size). Additionally, most deals are horizontal, or they involve firms in related industries. Acquired targets were also generally growing in sales, but combined firms were still relatively small with the majority having less than 100 million Euro in annual sales. In Table 2, we display the location of the acquiring and target firms, and many of the deals involve cross-border acquisitions with domestic acquisitions more common in Germany and Sweden. Additionally, few of the acquisitions include developing counties, but the distribution of acquiring and target countries are comparable to official statistics. Consequently, sampling bias does not appear to be a serious limitation for our study

--- Insert Table 1 about here ---

--- Insert Table 2 about here ---

\section{Evaluation of the Hypotheses}

For assessing our hypothesis, we used OLS regressions, as it accommodates interval scales. For the analysis of the moderating effects, we followed the advices of Baron and Kenny 
(1986) to standardize variables before calculating the interaction terms (Irwin \& McCelland, 2001). We first analyzed the correlations of our indicators and constructs for potential multicollinearity problems, see Table 3 . All correlations are below the suggested threshold of 0.8 (Gujarati, 1995). However, there is a high correlation between labor market flexibility and efficiency $(r=0.701)$. We also analyzed the variance inflation factor (VIF) for each regression model. The VIF's range between 1.057 and 4.033 and thus, are below the recommended threshold of 10 (Tabachnick \& Fidell, 2012). Again, the results suggest no multicollinearity problems. Our sample also shows a positive correlation between transaction type and performance, and this is consistent with conglomerate acquisitions performing better in our sample. Additionally, performance is better for the acquisition of growing targets. Interestingly, a correlation between the acquirer size in terms of annual sales and the acquisition experience $(.383 ; \mathrm{p}<.01)$ exists, and this is consistent with firm size being an indicator of acquisition activity. Consistent with Hypothesis 2a, functional integration is also correlated with acquisition performance.

\section{--- Insert Table 3 about here ---}

Table 4 reports the results of the regression analysis. We report standardized regression coefficients, F-Values as well as the adjusted $\mathrm{R}^{2}$ values, and our explanation of observed variance is consistent with other acquisition research (e.g., Sirower, 1997, p.158). In model 1 , we investigate the effects of the control variables, and the adjusted $\mathrm{R}^{2}$ indicates that the control variables explain only $5.2 \%$ of the variance of our dependent variable. In model 2 , we implemented the direct effects of human and functional integration speed. We find no significant effect from human integration speed on performance, and neither Hypothesis 1a nor $1 \mathrm{~b}$ is supported. For functional integration speed, we find a significant and positive effect indicating that fast functional integration increases acquisition performance, supporting Hypothesis H2a. As a result, we cannot support the alternative hypothesis (H2b) that indicated a negative performance effect. In model 3, we add the direct effects of the moderating 
variables. Only labor market flexibility has a negative direct performance effect $(\Omega=-.175$; $\mathrm{p}<.1)$

--- Insert Table 4 about here ---

In model 4, we implement the four interaction terms. Both direct effects, as suggested in $\mathrm{H} 1$ and $\mathrm{H} 2$, remain equal compared to models 2 and 3 with regards to significance and direction. While human integration speed is still insignificant, functional integration speed remains positive and significant $(\beta=.137 ; \mathrm{p}<.1)$. The interaction effects are significant and show diverging directions as indicated by H3 and H4. Specifically, H3a indicated a positive moderating effect of labor market flexibility on the human integration speed performance relationship. We find support for the theoretical relationship, as well as for the more complex performance relationships of human integration speed. Slow human integration is beneficial in cases of a rigid labor market and fast integration is beneficial for high labor market flexibility $(\beta=.188 ; \mathrm{p}<.1)$. This supports Hypothesis H3a and the effects are displayed in Figure 1. Further, we find a negative moderating effect of labor market flexibility on the relationship of functional integration speed on acquisition performance $(\beta=-.213 ; p<.05)$, supporting Hypothesis H3b. The performance effects between high and low labor market flexibility do not differ in cases of slow functional integration speed. However, Figure 2 shows that highly flexible labor markets negatively and less flexible labor markets positively impact the functional integration speed performance relationship. These results suggest that labor market factor conditions influence the impact of human and task integration on acquisition performance.

--- Insert Figure 1 about here ---

--- Insert Figure 2 about here ---

For Hypotheses $\mathrm{H} 4 \mathrm{a}$ and $\mathrm{H} 4 \mathrm{~b}$, we find significant moderating relationships. Hypothesis $\mathrm{H} 4 \mathrm{a}$ indicated a negative moderating effect of labor market efficiency on the relationship of human integration speed on acquisition performance. Our empirical results 
indicate a negative interaction $(\beta=-.318 ; \mathrm{p}<.01)$. Figure 3 shows that slow human integration speed is more beneficial in efficient labor markets, and fast human integration speed has a positive impact in less efficient labor markets. For Hypotheses H4b, we find the opposite effect for functional integration speed $(\beta=.361 ; \mathrm{p}<.01)$. As Figure 4 confirms, the beneficial effects of fast functional integration speed require efficient labor markets, and there is no benefit of when labor markets are inefficient.

--- Insert Figure 3 about here ---

--- Insert Figure 4 about here ---

\section{Supplemental analysis and Robustness Tests}

We performed supplemental analysis to test the robustness of our results. First, acquisition motives might impact integration approaches (Lebedev et al., 2015). For example, there is evidence that integration may destroy value in high-technology acquisitions (Puranam et al., 2009; Paruchuri et al., 2006), but provide benefits in other industries (e.g. Cording et al., 2008). While our focus on traditional industries should limit motives, as evidenced by a high proportion of horizontal acquisitions, we tested whether our effects are robust across acquisition motives (e.g. market-share, new product development, product-portfolio), operational aims (e.g. staff retention, headcount-reduction, customer retention), and financial aims (e.g. annual sales, operating income, cost savings). Each construct was assessed with a single item on a 7 point Likert scale ranging from 1= "not important" to 7= "very important", as controls to our regression model. The results show that strategic $(\beta=0.150 ; p=0.029)$ and financial $(\beta=0.267 ; p=0.000)$ motives impact acquisition performance, while operational aims do not. However, our proposed interaction-effects do not change with regards to either direction or significance $(H 3 a: \beta=0.182 ; p=0.058 ; H 3 b: \beta=-0.236 ; p=0.008 ; H 4 a: \beta=-$ 0.236; $\mathrm{p}=0.020 ; \mathrm{H} 4 \mathrm{~b}: \beta=0.362 ; \mathrm{p}=0.003)$. Additionally, we tested whether integration approaches are affected by acquisition motives. We find that strategic motives correlate with faster human integration speed and that strategic and operational motives correlate with faster 
functional integration speed. A relationship between functional integration and operational motives in acquisitions has face validity, as functional integration would be required to achieve operational motives.

Second, geographical and cultural distance might impact the chosen integration approach (Dow \& Larimo, 2011), as well as our research model. Consequently, we examined acquiring and target countries into the German-speaking, Scandinavian, other European, and countries outside Europe. Based on a parametric test, we find no significant differences between the subgroups and integration speed. We also transformed our country variables in two dummy variables to determine whether the acquirer and the target share a common cultural background in terms of sharing an official language or whether they belong to the same geographical region (Rossi \& Volpin, 2004). Again, we find no statistical differences regarding integration speed for either direction or significance.

As we have used a broad variety of control variables to avoid concerns regarding omitted variables bias, model-overfitting might be a serious concern (Zaheer et al., 2013). As a consequence, we calculated extended (with acquisition aims, language, and geographic dummy) and reduced models (without controls). Both, the extended, as well as the reduced models, provide consistent results, suggesting our findings are not artifacts of model specification.

\section{DISCUSSION}

Against a background where existing acquisition research largely applies an internal focus on combining firms (Teerikangas \& Joseph, 2012), we agree with $\mathrm{Wu}$ and colleagues (2016) that research needs to consider institutional contexts. Our research answers to calls to examine the institutional environment (Ferreira, et al., 2014; Hutzschenreuter, Kleindienst, \& Lange, 2015) and contingent effects of labor market factor conditions (Buckley et al., 2016; Siegel \& Larson, 2009). As a result, we complement earlier research on the constraining nature of the institutional environment (Capron \& Guillén, 2009). Further, our results confirm expectations 
of new institutional economics (North, 1990) that institutions in developed economies impact economic growth. We contribute to this line of research by confirming institutional setting of host and parent firm countries interact in realizing opportunities from acquisitions.

Specifically, our results show different direct effects for human and functional integration speed with an insignificant direct effect for human integration speed and a positive direct effect of functional integration speed on acquisition performance without considering institutional context. This can be partially explained by our focus on manufacturing industries where operational integration plays a major role.

We also find the impact of human and task integration speed is moderated by labor market factor conditions. Our results supporting the impact of human integration speed is positively moderated by labor market flexibility and negatively moderated by labor market efficiency. Consistent with expectations human integration speed becomes positive when paired with property rights, free markets, and competition typical of high labor market flexibility., However, the interaction of human integration speed and labor market efficiency is opposite of what was expected, and it lowers acquisition performance. Understanding the relationship between human integration speed and labor market efficiency represents an opportunity for future research. For functional integration speed, a slower pace of integration benefits performance when a host country has high labor market flexibility. However, this may be offset under conditions of labor market efficiency that amplifies the positive effect of functional integration speed on acquisition performance. Further, faster human integration under conditions of labor market flexibility may facilitate functional integration and improved acquisition performance. In discussing implications of our findings, we separately highlight research and managerial implications.

\section{Research implications}


Extant acquisition theory suffers from lack of attention to the environment surrounding acquisitions (Teerikangas \& Joseph, 2012; King \& Schriber, 2016). The majority of research on integration speed focuses on characteristics internal to combining firms (e.g., Angwin, 2004; Bauer, King \& Matzler, 2016; Cording et al., 2008; Homburg \& Bucerius, 2006), unlikely to sufficiently explain acquisition performance especially when combining firms from different environments. While prior research largely assumes that cultural distance is symmetrical between countries (Weber, Tarba \& Reichel, 2009), we find integration decisions and their outcomes will vary between two countries depending on where a target and acquirer are located. Further, most research on cross-border acquisitions has examined cultural differences versus more fine-grained institutional differences. In a review, Lebedev and colleagues (2015) conclude that the quality of institutions is important for cross-border acquisition performance. We complement and extend this research by examining whether institutional differences involving labor market efficiency and flexibility also impact crossborder acquisition decisions and performance.

Second, extant acquisition research acknowledges integration speed as one of the most important levers of acquiring managers, however often either disregards interaction with institutional contexts (e.g. Homburg \& Bucerius, 2006), and offers conflicting findings on speed. Our focus on the institutional environment can reconcile conflicting findings regarding the benefits (e.g., Chanmugan, et al., 2005; Cording et al., 2008; Morag \& Barakonyi, 2009) and drawbacks (Meglio et al., 2015; Puranam et al., 2009; Weber et al., 2009) of integration speed. We find that the interaction of integration decisions and institutional conditions significantly impact acquisition performance. Specifically, labor market efficiency and flexibility largely impacts acquisition performance through a moderating impact on human and task integration speed. This confirms the importance of labor market flexibility and efficiency as an important part of a nation's institutional environment (Whang, Hong, Kafouros \& Wright, 2012). Our results suggest tighter labor regulations lead to more 
organizational effort and reorganization costs, but they also reinforce the importance of human and functional integration speed. Further, faster human integration can mitigate limits of tighter labor markets. However, contrary to theory, the interaction between human integration speed and labor market efficiency had a negative opposite effect and underscores the need for continued research. Importantly, we find that it is not only the absolute value of differences, but the direction of the differences that matter (Hutzschenreuter, Kleindienst, \& Lange, 2016).

Third, our study also adds to new institutional economics (North, 1990) by showing how it offers a fruitful starting point for understanding acquisition performance. Prior research has begun to elaborate the effects of institutions on acquisitions involving developing countries (Hoskisson et al., 2013; Lebedev et al., 2015). While institutional differences may be the starkest in acquisitions involving developing and developed countries, we demonstrate they matter also in between developed countries. Thus, we extend and develop this research by further strengthening the relation between acquisitions and opportunities and threats from institutional context differences. Specifically, we show how institutions interact with acquisition choices to shape acquisition outcomes also in developed countries.

\section{Managerial implications}

Our results also have important implications for managers. First, integration speed can be a decisive success-factor in acquisitions. Nonetheless, the positive effect of functional integration speed should not automatically lead to the conclusion that managers should speed up the integration of organizational functions. Managers should set integration speed with consideration of an acquisition's context. In cases of a highly flexible labor market, key employees could easily leave the organization when changes are too disruptive. Thus, human resource management should focus on retaining these employees (Zhang, Ahammad, Tarba, Cooper, Glaister \& Wang, 2015). Still, it is likely more important that a market displays labor market efficiency where managers need to be more concerned with functional integration 
speed. This underscores that acquisition integration is a multidimensional construct and that managers need to consider the interplay between human and functional integration speed.

\section{Limitations and Research Opportunities}

Our study has several limitations worth noting, including our application of retrospective primary data to measure acquisition performance. This relates to concerns about the decreasing capacity of recollection and overly positive assessments by managers (Ellis, Reus \& Lamont, 2009; Golden, 1992). However, we attempt to mitigate this concern by focusing on more recent acquisitions. Research also supports that managerial assessment of firm performance is consistent with objective measures of performance (Richard et al., 2009). Further, managerial assessment is often the only available option and has the advantage of managers being able to consider multiple dimensions of performance (Papadakis \& Thanos, 2010). Still, examining the impact of labor market flexibility and efficiency on acquisition integration with objective performance measures to triangulate our results represents an opportunity for future research. A related limitation derives from a smaller sample size, though the significance of our observed effects could become even stronger in a larger sample. Regardless, our sample has the advantage of considering respondents from multiple countries, and our response rate is consistent with other primary data research on acquisitions (Bauer \& Matzler, 2014; Homburg \& Bucerius, 2006).

Additional changes in research design also represent opportunities. For example, future research should repeat this study to build cumulative knowledge in the field of integration and institutions (Bettis, Ethiraj, Gambardella, Helfat \& Mitchell, 2016; Lewin, Chiu, Fey, Levine, McDermott, Murmann, \& Tsang, 2016). Additionally, the majority of cross-border acquisition research focuses on developed country acquirers (Lebedev et al., 2015), and, while we do not find differences for acquisitions involving developing economies, there continues to be a need to examine acquisition activity by emerging market firms (Liu \& Vrontis, 2017; Collison, Brennan, \& Rios-Morales, 2017) and their interaction with 
institutions (e.g. protection of firm founders) or corporate governance (Young et al., 2008), as there is an increased trend of acquisitions by firms in emerging markets (Liu \& Deng, 2014; Xing, Liu, Tarba \& Cooper, 2016; Xing, Liu, Tarba, \& Cooper, 2017). Further, while we complement our primary data with secondary data on labor market characteristics, research in this area could benefit a longitudinal design would be preferable (Ellis, Reus, \& Lamont, 2009; Zollo \& Meier, 2008). Our measure of acquisition experience also focuses on general experience, and it would be useful to investigate prior acquisition experience in a target firm's country (e.g., Andersson \& Svensson, 1994), as well as a target firm's experience (e.g., Cuypers, Cuypers, \& Martin, 2016). Still, alternate research designs represent an opportunity for future research.

Overall, our findings reinforce Hutzschenreuter and colleagues (2016) suggestion that future research also consider additional aspects of institutional environment beyond labor market efficiency and flexibility (e.g., Liou, Chao \& Ellstrand, 2017; Sternard \& Sauermann, 2016). Research is also needed on the microfoundations of cross-border acquisitions, particularly considerations of the impacts on people and how they react (e.g., Liu et al., 2017). Still, most research on acquisition integration takes an internal focus, and we find an interaction between internal and external conditions better explains cross-border acquisition performance. 


\section{References}

Aguilera, R. V., \& Dencker, J. C. (2004): The role of human resource management in cross-border mergers and acquisitions. The International Journal of Human Resource Management, 15(8): 1355-1370.

Ahammad, M., Glaister, K., Weber, Y., \& Tarba, S. (2012): Top management retention in cross-border acquisitions: The roles of financial incentives, acquirer's commitment and autonomy. European Journal International Management, Vol. 6: 458-480.

Ahammad, M. F., Tarba, S. Y., Liu, Y., \& Glaister, K. W. (2014): Knowledge transfer and cross-border acquisition performance: The impact of cultural distance and employee retention. International Business Review, 25(1): 66-75.

Akgün, A., \& Lynn, G. (2002): New product development team improvisation and speed-to-market: an extended model. European Journal of Innovation Management, 5(3): 117-29.

Alimov, A. (2015): Labor market regulations and cross-border mergers and acquisitions. Journal of International Business Studies, 46(8): 984-1009.

Andersson, T., \& Svensson, R. (1994). Entry modes for direct investment determined by the composition of firm-specific skills, Scandinavian Journal of Economics, 96: 551-560.

Ang, S. H., Benischke, M. H. \& Doh, J. P. (2015). The interactions of institutions on foreign market entry mode, Strategic Management Journal, 36, pp. 1536-1553.

Angwin, D. (2004): Speed in M\&A integration: The first 100 days. European Management Journal, Vol. 22(4): 418-430.

Angwin, D., \& Meadows, M. (2015): New integration strategies for post-acquisition management. Long Range Planning, Vol. 48(4): 235-251.

Anner, M., \& Caraway, T. (2010): International institutions and workers' rights: Between labor standards and market flexibility. Studies in Comparative International Development, 45(2): 151-169.

Appelbaum, S. H., Gandell, J., Yortis, H., Proper, S., \& Jobin, F. (2000): Anatomy of a merger: behavior of organizational factors and processes throughout the pre-during-post-stages (part1). Management Decision, Vol. 38(9): 649-661.

Armstrong, S. J., \& Overton, T. S. (1977): Estimating Nonresponse Bias in Mail Surveys. Journal of Marketing Research, Vol. 14: 396-402.

Bagchi, P., \& Rao, R. P. (1992): Decision making in mergers: An application of the analytic hierarchy process. Managerial Decision Economics, Vol. 13: 91-99.

Barkema, H. G., \& Schijven, M. (2008): How do firms learn to make acquisitions? A review of past research and an agenda for the future. Journal of Management, Vol. 30(4): 594-634.

Baron, R., \& Kenny, D. (1986): The moderator-mediator variable distinction in social psychological research: Conceptual, strategic, and statistical distinctions. Journal of Personality and Social Psychology, Vol. 51(6): 1173-1182.

Bauer, F., \& Matzler, K. (2014): Antecedents of M\&A success: The role of strategic complementarity, cultural fit, and degree and speed of integration. Strategic Management Journal, Vol. 35(2): 1-23.

Bauer, F., King, D., \& Matzler, K. (2016): Speed of acquisition integration: Separating the role of human and task integration. Scandinavian Journal of Management, Vol. 32: 150-165.

Bauer F. (2016): A literature review and a suggestive future research agenda on speed of integration in M\&A Tacking stock of what we know, in: Risberg, A., King, D.R., \& Meglio, O. (Eds.): The Routledge Companion to Mergers and Acquisitions, Routledge, London, New York

Bauer, F., Dao, M.A., Matzler, K., \& Tarba, S.Y. (2017): How industry lifecycle sets boundary conditions for M\&A integration. Long Range Planning, 50(4): 501-517. 
Becker, D. (2005): Ressourcen-Fit bei M\&A-Transaktionen - Konzeptionalisierung, Operationalisierung und Erfolgswirkung auf Basis des Resourcebased View. Wiesbaden: Gabler Verlag.

Belenzon, S., Tsolmon, U., (2016). Market frictions and the competitive advantage of internal labor markets. Strategic Management Journal 37: 1280-1303.

Bettis, R. A., Ethiraj, S., Gambardella, A., Helfat, C., \& Mitchell, W. (2016): Creating repeatable cumulative knowledge in strategic management - A call for a broad and deep conversation among authors, referees, and editors. Strategic Management Journal, 37(2): 257-261.

Bijlsma-Frankema, K. (2004): Dilemmas of managerial control in post-acquisition processes. Journal of Managerial Psychology, 19: 252-268.

Birkinshaw, J., Bresman, H., \& Hakanson, L. (2000): Managing the post acquisition integration process: How human integration and task integration processes interact to foster value creation. Journal of Management Studies, Vol. 37(3): 365-425.

Botero, J. C., Djankov, S., Porta, R.L., Lopez-de-Silanes, F., \& Shleifer, A. (2004). The Regulation of Labor. Quarterly Journal of Economics 119 (4): 1339-1382.

Breen, R. (2005). Explaining cross-national variation in youth unemployment: Market and institutional factors. European Sociological Review, 21(2): 125-134.

Brozovic, D. (forthcoming): Strategic flexibility: A review of the literature. International Journal of Management Reviews: 1-29.

Brueller, N., Carmeli, A., \& Markman, G. (forthcoming): Linking merger and acquisition strategies to post merger integration: A configurational perspective of human resource management. Journal of Management.

Buckley, P.J., Munjal, S., Enderwick, P., \& Forsans, N. (2016): Do foreign resources assist or impede internationalisiation? Evidence from internationalization of Indian multinational enterprises. International Business Review, 25: 130-140.

Buono, A., \& Bowditch, J. L. (2003): The human side of mergers and acquisitions - managing collisions between people, cultures and organizations. Washington D.C.

Calipha, R., Tarba, S. Y., \& Brock, D. M. (2010): Mergers and acquisitions: A review of phases, motives, and success factors. Advances in Mergers and Acquisitions, 9: 1-24.

Capron, L., Dussauge, P., \& Mitchell, W. (1998): Resource redeployment following horizontal acquisitions in Europe and North America, 1988-1992. Strategic Management Journal, 19(7): 631-661.

Capron, L., \& Guillén, M. (2009): National corporate governance institutions and post acquisition reorganization. Strategic Management Journal, Vol. 30: 803-833.

Carbonell, P., Rodriguez-Escudero, A., \& Pujari, D. (2009): Customer involvement in new service development: An examination of antecedents and outcomes. The Journal of Product Innovation Management, 26: 536-550.

Cartwright, S. (2005): Mergers and acquisitions: An update and appraisal. International Review of Industrial and Organizational Psychology, Vol. 20: 1-38.

Carney, M., Dieleman, M. and Taussig, M. (2016). How are institutional capabilities transferred across borders? Journal of World Business, 51: 882-894.

Chacar, A. S., Newburry, W., Vissa, B., \& Chacar, A. (2010): Bringing institutions into performance persistence research: Exploring the impact of product, financial, and labor market institutions. Journal of International Business Studies, 41(7): 1119-1140.

Chanmugam, R., Shill, W., Mann, D., Ficery, K., \& Pursche, B. (2005): The intelligent clean room: Ensuring value capture in mergers and acquisitions. Journal of Business Strategy, 26(3): 43-49.

Choi, J. J., Lee, S. M. \& Shoham, A. (2016). The effects of institutional distance on FDI inflow: General environmental institutions (GEI) versus minority investor protection institutions (MIP), International Business Review, 25, pp. 114-123 
Christensen, C. M., Alton, R., Rising, C., \& Waldeck, A. (2011): The new M\&A playbook. Harvard Business Review, March: 48-57.

Churchill, G. A. (1995): Marketing research: Methodological foundations (6th ed.). New York.

Collings, D., Scullion, H., \& Morley, M. (2007): Changing patterns of global staffing in the multinational enterprise: Challenges to the conventional expatriate assignment and emerging alternatives. Journal of World Business, Vol. 42: 198-213.

Collison, P., Brennan, L. \& Rios-Morales, R. (2017). Attracting Chinese Foreign Direct Investment to Small, Developed Economies: The Case of Ireland, Thunderbird International Business Review, 59: 401-419.

Cogman, D., Tan, J. (2010), A lighter touch for post-merger integration, McKinsey Quarterly, 34: 8-12.

Cooke, F. L. (2006): Acquisitions of Chinese State-Owned Enterprises by Multinational Corporations: Driving Forces, Barriers and Implications for HRM. British Journal of Management, 17(S1): 105-S121.

Cooke, F. L., \& Huang, K. (2011): Postacquisition evolution of the appraisal and reward systems: A study of Chinese IT firms acquired by US firms. Human Resource Management, Vol. 50(6): 839-858.

Cording, M., Christman, P., \& King, D. (2008): Reducing causal ambiguity in acquisition integration: Intermediate goals as mediators of integration decisions and acquisition performance. Academy of Management Journal, Vol. 51(4): 744-767.

Cording, M., Christmann, P., \& Weigelt, C. (2010). Measuring theoretically complex constructs: The case of acquisition performance. Strategic Organization, Vol. 8 (1): 11-41.

Cuypers, I. R., Cuypers, Y., \& Martin, X. (2017). When the target may know better: Effects of experience and information asymmetries on value from mergers and acquisitions. Strategic Management Journal, 38(3): 609625.

Datta, D. (1991): Organizational fit and acquisition performance: Effects on post acquisition integration. Strategic Management Journal, Vol. 12(4): 281-297.

Debroux, P. (1993): Japanese mergers and acquisitions: Overcoming obstacles to improved systemic efficiency. Atlantic Economic Journal, Vol. 24(3): 224-256.

De Massis, A., Audretsch, D., Uhlaner, L., \& Kammerlander, N. (2017): Innovation with limited resources: Management lessons from the German Mittelstand. Journal of Product Innovation Management, online first

Dikova, D., Sahib, P., \& Wittleoostuijn, A. (2010): Cross-broader acquisition abandonment and completion: The effect of institutional differences and organizational learning in the international business service industry, 19812001. Journal of International Business Studies, 41: 223-245.

Dillman, D. (2000): Mail and Internet Surveys: The Tailored Design Method (2nd. ed.). New York: Wiley.

Dillman, D., Smyth, J., \& Christian, L. (2009): Internet, mail, and mixed mode surveys: the tailored design method. Hoboken: Wiley \& Sons.

DiPrete, T.A. (1993): Industrial restructuring and the mobility response of American workers in the 1980s. American Sociological Review, 58(1): 74-96.

Dow, D., \& Larimo, J. (2011): Disentangling the roles of international experience and distance in establishment mode choice. Management International Review, 51: 321-355.

Eckardt, R., Skaggs, B., Youndt, M. (2014): Turnover and knowledge loss: An examination of the differential impact of production manager and worker turnover in service and manufacturing firms. Journal of Management Studies, Vol. 51: 1025-1057.

Ellis, K., Reus, T., \& Lamont, B. (2009): The effects of procedural and informational justice in the integration of related acquisitions. Strategic Management Journal, Vol. 30 (2): 137-161.

Ellis, K., Reus, T., Lamont, B., \& Ranft, A. (2011): Transfer effects in large acquisitions: How size specific experience matters. Academy of Management Journal, Vol. 6: 1261-1276. 
Faundez, J. (2016) Douglas North's theory of institutions: Lessons for law and development, Hague Journal on the Rule of Law, 8(2): 373-419.

Ferreira, M., Santos, J., de Almeida, M., \& Reis, N. (2014): Mergers and acquisitions research: A bibliometric study of top strategy and international business journals, 1980-2010. Journal of Business Research, 67(12): 2550-2558.

Gates, S., \& Very, P. (2003): Measuring performance during M\&A integration, Long Range Planning, 36: 167185 .

Giovanni, J. (2005): What drives capital flows? The case of cross-border M\&A activity and financial deepening, Journal of International Economics, 65(1): 127-149.

Goktan, A., \& Miles, G. (2011): Innovation speed and radicalness: are they inversely related? Management Decision, 49(4): 533-47.

Golden, B. (1992): The past is the past - or is it? The use of retrospective accounts as indicators of past strategy. Academy of Management Journal, Vol. 35(4): 848-860.

Graebner, M. E. (2004): Momentum and serendipity: How acquired leaders create value in the integration of technology firms. Strategic Management Journal, Vol. 25(8-9): 751-777.

Greig, F. (2008). Propensity to negotiate and career advancement: Evidence from an investment bank that women are on a "slow elevator". Negotiation Journal, 24(4): 495-508.

Gujarati, D. (1995). Basic econometrics, 3rd ed. New York: McGraw-Hill.

Hambrick, D.C., \& Cannella, A.A. (1993): Relative standing: A framework for understanding departures of acquired executives. Academy of Management Journal, Vol. 36(4): 733-762.

Harrison, D. M., McLaughlin, M.E., \& Coalter, T.M. (1996): Context, cognation, and common method variance: psychometric and verbal protocol evidence. Organization Behaviour and Human Decision Processes, Vol. 68(3): 246-261.

Haspeslagh, P. C., \& Jemison, D. B. (1991): Managing Aacquisitions. New York.

Hitt, M., King, D., Krishnan, H., Makri, M., Schijven, M., Shimizu, K., \& Zhu, H. (2009): Mergers and acquisitions: Overcoming pitfalls, building synergy, and creating value. Business Horizons, Vol. 52(6): 523-529.

Holmund, M., Kock, S., \& Vanyushyn, V. (2007): Small and medium-sized enterprises' internationalization and the influence of importing on exporting, International Small Business Journal, 25(5): 459-475.

Homburg, C., \& Bucerius, M. (2005): A marketing perspective on mergers and acquisitions: How marketing integration affects postmerger performance. Journal of Marketing, Vol. 69: 96-113.

Homburg, C., \& Bucerius, M. (2006): Is speed of integration really a success factor of mergers and acquisitions? An analysis of the role of internal and external relatedness. Strategic Management Journal, Vol. 27: 347-367.

Hoskisson, R., Wright, M., Filatotchev, I., Peng, M. 2013. Emerging multinationals from mid-range economies: The influence of institutions and factor markets. Journal of Management Studies, 50: 1295-1321.

Hutzschenreuter, T., Kleindienst, I. \& Lange, S. (2016). The Concept of Distance in International Business Research: A Review and Research Agenda, International Journal of Management Reviews, 18: 160-179.

Irwin, J., \& McCelland, G. (2001): Misleading heuristics for moderated multiple regression models. Journal of Marketing Research, Vol. 38: 100-109.

Jemison, D.B., \& Sitkin, S.B. (1986). Corporate Acquisitions: A Process Perspective. Academy of Management Review 11: 145-163.

Keil, T., Laamanen, T., \& McGrath, R. (2013): Is a counterattack the best defense? Competitive dynamics through acquisitions. Long Range Planning, Vol. 46: 195-215. 
Kessler, E.H., \& Bierly, P. (2002): Is faster really better? An empirical test of the implications of innovation speed. IEEE Transactions on Engineering Management, 49(1): 2-12.

Khan, Z., Soundararajan, V., Wood, G. and Ahammad, M. F. (2017). Employee emotional resilience during post-merger integration across national boundaries: Rewards and the mediating role of fairness norms, Journal of World Business. DOI: 10.1016/j.jwb.2017.06.009.

Kim, H., \& Song, J. (2017): Filing institutional voids in emerging economies: The impact of capital market development and business groups on M\&A deal abandonment. Journal of International Business Studies, 48(3): 308-323.

King, D., Dalton, D. R., Daily, C. M., \& Covin, J. G. (2004): Meta-analyses of post-acquisition performance: Indications of unidentified moderators. Strategic Management Journal, Vol. 25: 187-200.

King, D., \& Schriber, S. (2016): Addressing competitive responses to acquisitions. California Management Review, Vol. 58(1): 109-124.

Kostova, T. (1999): Transfer of strategic organizational practices: a contextual perspective. Academy of Management Review, Vol. 24(2): 308-324.

Kostova, T., \& Roth, K. (2002). Adoption of an organizational practice by subsidiaries of multinational corporations: Institutional and relational effects. Academy of Management Journal, 45(1), 215-233.

Krishnan, H., Hitt, M., \& Park, D. (2007): Acquisition premiums, subsequent workforce reductions and postacquisition performance. Journal of Management Studies, Vol. 44: 709-732.

Lakshman, C. (2011): Post acquisition cultural integration in mergers \& acquisitions: A knowledge-based approach. Human Resource Management, Vol. 50(5): 605-623.

Larsson, R., \& Finkelstein, S. (1999): Integrating strategic, organizational, and human resource perspectives on mergers and acquisitions: A case survey of synergy realization. Organizational Science, Vol. 10(1): 1-26.

Lazear, E.P. (1998): Personnel economics: Past lessons and future directions. Journal of Labor Economics, 17(2): 1999-236.

Lebedev, S., Peng, M., Xie, E., Stevens, C. (2015). Mergers and acquisitions in and out of emerging economies, Journal of World Business, 50: 651-662.

Lee, J., Park, N. K., \& Kim, H. (2014): The effect of change in organizational identity on knowledge creation by mobile R\&D workers in M\&As. Journal of Organizational Change Management, 27: 41-58.

Lewin, A. Y., Chiu, C.-Y., Fey, C. F., Levine, S. S., McDermott, G., Murmann, J. P., \& Tsang, E. (2016): The critique of empirical social science: New policies at management and organization review. Management and Organization Review, 12: 649-658.

Liou, R. S., Chao, M. C., \& Ellstrand, A. (2017): Unpacking Institutional Distance: Addressing Human Capital Development and Emerging-Market Firms' Ownership Strategy in an Advanced Economy. Thunderbird International Business Review, 59(3): 281-295.

Liu, Y. \& Deng, P. (2014). Chinese cross-border M\&A: Past achievement, contemporary debates and future direction, Advances in Mergers and Acquisitions, 13: 85-107.

Liu, Y., Sarala, R.M., Xing, Y., \& Cooper, C.L. (2017): Human side of collaborative partnerships - A microfoundational perspective. Group and Organization Management, 42(2): 151-162.

Liu, Y. \& Vrontis, D. (2017). Emerging-Market Firms Venturing into Advanced Economies: The Role of Context, Thunderbird International Business Review, 59: 255-261.

Liu, Y., \& Woywode, M. (2013). Light-touch Integration of Chinese Cross-Border M\&A: The Influences of Culture and Absorptive Capacity, Thunderbird International Business Review. Vol. 55(4): 469-483.

Lord, M.D., \& Ranft, A.L. (2000): Organizational learning about new international markets: exploring the internal transfer of local market knowledge. Journal of International Business Studies, Vol. 31(4): 573-589. 
Makino, S., Isobe, T., \& Chan, C. M. (2004). Does country matter? Strategic Management Journal, 25(10), 1027-1043.

Mayer, D., \& Kenney, M. (2004): Economic action does not take place in a vacuum: Understanding Cisco's acquisition and development strategy. Industry and Innovation, Vol. 11(4): 299-325.

Meyer, K.E., \& Peng, M.W. (2016): Theoretical foundations of emerging economy business research. Journal of International Business Studies, 47(1): 3-22.

Meglio, O., \& Risberg, A. (2010): Mergers and acquisitions-Time for a methodological rejuvenation in the field? Scandinavian Journal of Management, Vol. 26: 87-95.

Meglio, O., \& Risberg, A. (2011): The (mis)measurement of M\&A performance-A systematic narrative literature review. Scandinavian Journal of Management, 24: 418-433.

Meglio, O., King, D., \& Risberg, A. (2015): Improving acquisition outcomes with contextual ambidexterity. Human Resource Management, Vol. 54(S1): 29-43.

Meglio, O., King, DR., Risberg, A. (2017). Speed in acquisitions: A managerial framework. Business Horizons, 60(3): 415-425.

Mellahi, K., \& Collings, D. (2009): Strategic talent management: A review and research agenda. Human Resource Management Review, Vol. 19(4): 304-313.

Meschi, P. X., Phan, T. T., \& Wassmer, U. (2016): Transactional and institutional alignment of entry modes in transition economies. A survival analysis of joint ventures and wholly owned subsidiaries in Vietnam. International Business Review, 25(4): 946-959.

Meyer, K.E., Estrin, S., Bhaumik, S.K., \& Peng, M.W., (2009). Institutions, resources, and entry strategies in emerging economies. Strategic Management Journal 30, 61-80.

Miller, S. R., Lavie, D., \& Delios, A. (2016): International intensity, diversity, and distance: Unpacking the internationalization-performance relationship. International Business Review, 25(4): 907-920.

Morag, O., \& Barakonyi, K. (2009): The influence of speed of integration on M\&A integration success. VEZETĖSTUDOMÀNY, Vol. 11: 55-59.

Mortensen, D. T., \& Pissarides, C. A. (1994): Job Creation and Job Destruction in the Theory of Unemployment. The Review of Economic Studies, 61(3): 397-415.

Neffke, F., \& Henning, M. (2013): Skill relatedness and firm diversification. Strategic Management Journal, Vol. 34: 297-316.

Neumark, D., \& Wascher, W. (2004). Minimum wages, labor market institutions, and youth employment: a cross-national analysis. ILR Review, 57(2), 223-248.

North, D. C. 1990. Institutions, institutional change, and economic performance. New York: Norton.

Papadakis V, \& Thanos I. (2010): Measuring the performance of acquisitions: An empirical investigation using multiple criteria. British Journal of Management, Vol. 21(4): 859-873.

Paruchuri, S., Nerkar, A., \& Hambrick, D. C. (2006): Acquisition integration and productivity losses in the technical core: Disruption of inventors in acquired companies. Organization Science, Vol. 17: 545-562.

Paustian-Underdahl, S. C., Fainshmidt, S., Sanchez, J. I., Misati, E., Zhao, Y. \& Zhang, H. (2017). The Role of Economic Development and Perceived Growth Opportunities in Employee Reactions to M\&As: A Study of the Merger Syndrome Across 29 Countries, Group \& Organization Management, 42: 163-194.

Piketty, T. (2014): Capital in the 21st Century. Harvard: Boston, MA.

Podsakoff, P. M., \& Organ, D. W. (1986): Self-reports in organizational research: Problems and prospects. Journal of Management, Vol. 12(4): 531-544. 
Podsakoff, P. M., MacKenzie, S. B., Lee, J.-Y., \& Podsakoff, N. P. (2003): Common method biases in behavioral research: A critical review of the literature and recommended remedies. Journal of Applied Psychology, Vol. 88(5): 879-903.

Podsakoff, P. M., MacKenzie, S. B., \& Podsakoff, N. P. (2012): Sources of method bias in social science research and recommendations on how to control it. Annual Review of Psychology, Vol. 65: 539-569.

Puranam, P., Singh, H., \& Chaudhuri, S. (2009): Integrating acquired capabilities: When structural integration is (un) necessary. Organization Science, Vol. 20: 313-328.

Richard P, Devinney T, Yip G, \& Johnson G. (2009). Measuring organizational performance. Towards methodological best practice. Journal of Management, Vol. 35: 718-804.

Rossi, S., \& Volpin, P.F. (2004): Cross-country determinants of mergers and acquisitions. Journal of Financial Economics, 74: 277-304.

Sarala, R., Junni, P., Cooper, C., \& Tarba, S. (2016): A sociocultural perspective on knowledge transfer in mergers and acquisitions. Journal of Management, Vol. 42: 1230-1249.

Schlaepfer, R., di Paola, S., Kupiers, R., Brauchli-Rohrer, B., Marti, A., Brun, P., et al. (2008): How can leadership make a difference - an integration survey. PWC, pp. 1-16.

Schneper, W. D., \& Guillén, M. F. (2004): Stakeholder rights and corporate governance: A cross-national study of hostile takeovers. Administrative Science Quarterly, 49(2): 263-295.

Schweiger, D.M., \& Goulet, P.K. (2000): Integrating mergers and acquisitions: an international research review. Advances in Mergers and Acquisitions, 1: 61-91.

Schweiger, D., \& Goulet, P.K. (2005): Facilitating acquisition integration through deep-level cultural learning interventions: A longitudinal field experiment. Organization Studies, 26(10): 1477-1499.

Schweizer, L. (2005): Organizational integration of acquired biotechnology companies into pharmaceutical companies: The need for a hybrid approach. Academy of Management Journal, 48(6): 1051-1074.

Schweizer, L., Patzelt, H. (2012): Employee commitment in the post-acquisition integration process: The effect of integration speed and leadership. Scandinavian Journal of Management, Vol. 38: 298-310.

Scott, W.R., \& Davis, G.F. (2007): Organizations and Organizing: Rational, Natural, and Open System Perspectives, first ed. Pearson Prentice Hall, Upper Saddle River, N.J.

Shimizu, K., Hitt, M., Vaidyanath, D., \& Pisano, V. (2004): Theoretical foundations of cross-border mergers and acquisitions: A review of current research and recommendations for the future. Journal of International Management, Vol. 10: 307-353.

Shrivastava, P. (1986): Postmerger integration. The Journal of Business Strategy, Vol. 7(1): 65-76.

Siegel, D., \& Simons, K. (2010): Assessing the effects of mergers and acquisitions on firm performance, plant productivity, and workers: New evidence from matched employer-employee data. Strategic Management Journal, Vol. 31(8): 903-916.

Siegel, J. I. \& Larson, B. Z. (2009). Labor Market Institutions and Global Strategic Adaptation: Evidence from Lincoln Electric, Management Science, 55, pp. 1527-1546

Sirower, M.L. (1997): The synergy trap - How companies lose the acquisition game. The Free Press, New York.

Slangen, A. (2006): National cultural distance and initial foreign acquisition performance: The moderating effect of integration. Journal of World Business, Vol. 41: 161-170.

Slangen, A. H. L. \& van Tulder, R. J. M. (2009): Cultural distance, political risk, or governance quality? Towards a more accurate conceptualization and measurement of external uncertainty in foreign entry mode research. International Business Review, 18(3): 276-291.

Spector, P. (2006): Method variance in organizational research - Truth or urban legend? Organizational Research Methods, Vol. 9(2): 221-232. 
Steigenberger, N., (2016). The Challenge of Integration: A Review of the M\&A Integration Literature. International Journal of Management Reviews, 19(4): 408-431.

Stenard, B. S., \& Sauermann, H. (2016): Educational mismatch, work outcomes, and entry into entrepreneurship. Organization Science, 27(4): 801-824.

Stucchi, T. (2012): Emerging market firms' acquisitions in advanced markets: Matching strategy with resource-, institution- and industry-based antecedents, European Management Journal. 30(3), pp. 278-289.

Tabachnick, B.G., \& Fidell, L., (2012): Using Multivariate Statistics, sixth ed. Pearson Education Limited, Boston.

Teerikangas, S., \& Very, P. (2006): The culture-performance relationship in M\&A: From yes/no to how. British Journal of Management, Vol. 17: 31-48.

Teerikangas, S., \& Josep, R. (2012): Post-deal integration - an overview. In: Faulkner, D., Teerikangas, S., \& Josep, R.: The Handbook of Mergers and Acquisitions, Oxford, University Press

Teusler, N. (2008): Strategische Stabilitätsfaktoren in Unternehmenskooperationen - Eine kausalanalytische Betrachtung, Wiesbaden, Gabler.

Ullrich, J., van Dick, R. (2007): The group psychology of mergers and acquisitions: Lessons from the social identity approach. Advances in Mergers and Acquisitions, Vol. 6: 1-15.

Uzelac, B., Bauer, F., Matzler, K., \& Waschak, M. (2016): The moderating effects of decision-making preferences on M\&A integration speed and performance. The International Journal of Human Resource Management, Vol. 27(20): 2436-2460.

Vester, J. (2002): Lessons learned about integrating acquisitions. Research Technology Management, Vol. 45: 33-41.

Walsh, J. (1988): Top management turnover following mergers and acquisitions. Strategic Management Journal, Vol. 9(2): 173-183.

Wang, C., Hong, J., Kafouros, M., \& Wright, M. (2012). Exploring the role of government involvement in outward FDI from emerging economies. Journal of International Business Studies, 43(7): 655-676.

Weber, Y., Shenkar, O., \& Raveh, A. (1996): National and corporate cultural fit in mergers/acquisitions: An exploratory study. Management Science, Vol. 42: 1215-1227.

Weber, Y., Tarba, S.Y., \& Reichel, A. (2009): International mergers and acquisition performance revisited-the role of cultural distance and post-acquisition integration approach. Advances in Mergers and Acquisitions: 1-17.

Weber, Y., \& Fried, Y. (2011): Guest editors’ note: The dynamic of employees’ reactions during postmerger integration processes. Human Resource Management, Vol. 50(6): 777-781.

Weber, Y., Tarba, S.Y., \& Bachar, Z.R. (2011): Mergers and acquisitions performance paradox: the mediating role of integration approach. European Journal of International Management, Vol. 15(4): 373-393.

Weber, Y., \& Tarba, S.Y. (2013): Sociocultural integration in mergers and acquisitions-New perspectives. Thunderbird International Business Review, Vol. 55(4): 327-331.

Weetman, P., \& Gray, S. (1991): A comparative international analysis of the impact of accounting principles on profits: The USA versus the UK, Sweden, and the Netherlands. Accounting and Business Research, Vol. 21(84): 363-379.

Wu, J., Wang, C., Hong, J., Piperopoulos, P. \& Zhuo, S. (2016). Internationalization and innovation performance of emerging market enterprises: The role of host-country institutional development, Journal of World Business, 51, pp. 251-263.

Xing, Y., Liu, Y., Tarba, S. Y., \& Cooper, C. L. (2016): Intercultural influences on managing African employees of Chinese firms in Africa: Chinese managers' HRM practices. International Business Review, 25(1): $28-41$. 
Young, M. N., Peng, M. W., Ahlstrom, D., Bruton, G. D., \& Jiang, Y. (2008): Corporate Governance in Emerging Economies: A Review of the Principal-Principal Perspective. Journal of Management Studies, 45(1): 196-220.

Zaheer, A., Castaner, X., \& Sounder, D. (2013): Synergy sources, target autonomy, and integration in acquisitions. Journal of Management, Vol. 39(3): 604-632.

Zhang, J., Ahammad, M.F., Tarba, S.Y., Cooper, C.L., Glaister, K.W., \& Wang, J. (2015): The effect of leadership style on talent retention during Merger and Acquisition integration: Evidence from China. The International Journal of Human Resource Management, 26(7): 1021-1050.

Zheng, N., Wei, Y., Zhang, Y., \& Yang, J. (2014): In search of strategic assets through cross-border merger and acquisitions: Evidence from Chinese multinational enterprises in developed economies, International Business Review, 25(1): 177-186.

Zhu, H., Xia, J. and Makino, S. (2015). How do high-technology firms create value in international M\&A? Integration, autonomy and cross-border contingencies, Journal of World Business, 50: 718-728.

Zollo, M., \& Meier, D. (2008): What is M\&A performance. Academy of Management Perspectives, Vol. 22(3): $55-77$. 
Tables and Figures

Table 1: Descriptive Statistics

\begin{tabular}{|c|c|c|c|c|c|}
\hline Relative size & $\%$ & Branch growth & $\%$ & Annual sales of & \\
\hline$<25 \%$ & 41.9 & $>-15 \%$ & 4.4 & consolidated business in $€$ & \\
\hline $25 \%-49 \%$ & 22.2 & $-15 \%$ to $-5 \%$ & 6.9 & $<25$ million & 29.6 \\
\hline $50 \%-74 \%$ & 9.9 & $-5 \%$ to $+/-0 \%$ & 14.8 & 25-49 million & 17.7 \\
\hline $75 \%-100 \%$ & 16.7 & $+/-0 \%$ to $5 \%$ & 40.4 & 50-99 million & 20.7 \\
\hline \multirow[t]{4}{*}{$>100 \%$} & 9.4 & $5 \%$ to $10 \%$ & 18.7 & 100-249 million & 11.8 \\
\hline & & $11 \%$ to $20 \%$ & 11.3 & 250-499 million & 9.4 \\
\hline & & $21 \%$ to $30 \%$ & 2.5 & 500-1.000 million & 4.9 \\
\hline & & $>30 \%$ & 1.0 & $>1.000$ million & 5.9 \\
\hline $\begin{array}{l}\text { Type of } \\
\text { transaction }\end{array}$ & $\%$ & & & & In $\%$ \\
\hline Horizontal & 64.5 & & & Mergers & 5 \\
\hline Vertical & 25.6 & & & Acquisitions & 95 \\
\hline Conglomerate & 9.9 & & & & \\
\hline
\end{tabular}


Table 2: Acquirer and Target Countries

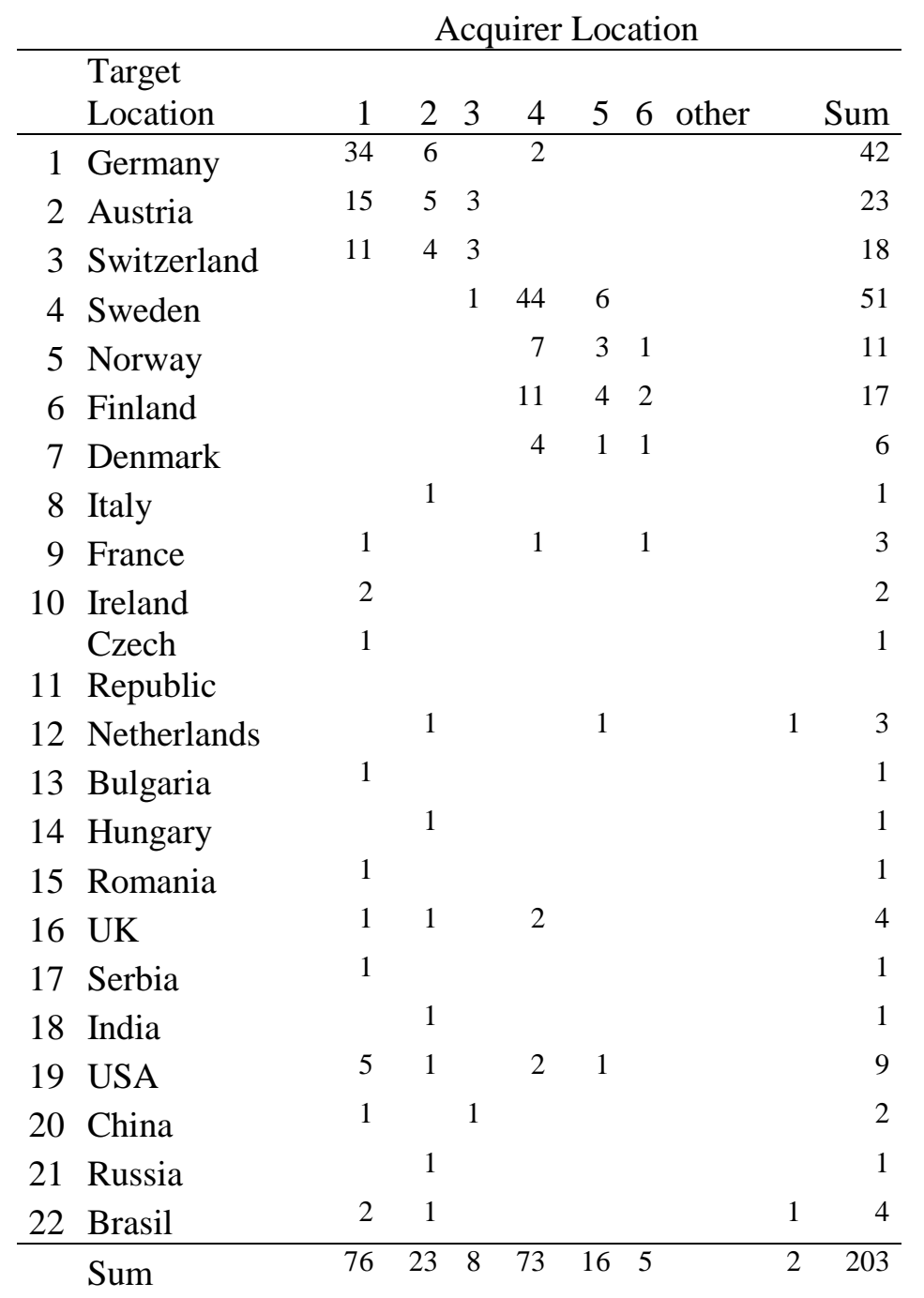


Table 3: Correlations among Variables

\begin{tabular}{|c|c|c|c|c|c|c|c|c|c|c|c|c|c|}
\hline & 1 & 2 & 3 & 4 & 5 & 6 & 7 & 8 & 9 & 10 & 11 & 12 & 13 \\
\hline 1 Performance & 1 & & & & & & & & & & & & \\
\hline 2 Relative Size & 0.016 & 1 & & & & & & & & & & & \\
\hline 3 Annual Sales & 0.054 & $-0.209 * *$ & 1 & & & & & & & & & & \\
\hline 4 Industry Growth & $0.230^{* *}$ & 0.100 & -0.072 & 1 & & & & & & & & & \\
\hline 5 Acquisition Experience & 0.051 & $-0.147^{*}$ & $0.383^{* *}$ & -0.075 & 1 & & & & & & & & \\
\hline 6 Transaction Type & $0.166^{*}$ & 0.041 & 0.050 & 0.080 & -0.006 & 1 & & & & & & & \\
\hline 7 Merger Acquisition & -0.008 & 0.033 & -0.103 & -0.018 & 0.033 & 0.060 & 1 & & & & & & \\
\hline 8 Competition Intensity & -0.029 & 0.038 & -0.067 & 0.057 & 0.011 & 0.075 & -0.002 & 1 & & & & & \\
\hline 9 Average Growth & $0.181^{* *}$ & 0.070 & -0.136 & $0.428^{* *}$ & -0.014 & 0.128 & 0.088 & -0.032 & 1 & & & & \\
\hline 10 Human Integration Speed & 0.080 & -0.101 & 0.083 & 0.052 & 0.104 & -0.105 & -0.015 & -0.045 & 0.072 & 1 & & & \\
\hline 11 Functional Integration Speed & $0.177^{*}$ & $-0.142^{*}$ & 0.007 & 0.054 & 0.079 & -0.029 & -0.062 & -0.044 & 0.053 & $0.448^{* *}$ & 1 & & \\
\hline 12 Labor Market Flexibility & -0.128 & 0.043 & $-0.194 *$ & 0.071 & 0.073 & -0.096 & -0.020 & 0.032 & 0.095 & 0.059 & 0.075 & 1 & \\
\hline 13 Labor Market Efficiency & -0.044 & -0.027 & -0.125 & 0.111 & 0.087 & 0.021 & -0.085 & $0.140 *$ & 0.036 & -0.032 & 0.126 & $0.701 * *$ & 1 \\
\hline Mean & 5.02 & 2.30 & 2.92 & 4.99 & 3.14 & 1.45 & 1.95 & 0.10 & 4.11 & 2.99 & 3.64 & 0.11 & -.06 \\
\hline STDV & 0.95 & 1.34 & 1.80 & 1.24 & 1.52 & 0.67 & 0.22 & 0.38 & 1.35 & 1.69 & 1.29 & 0.74 & 0.57 \\
\hline
\end{tabular}


Table 4: Regression Analysis

\begin{tabular}{lcccc}
\hline Performance & Model 1 & Model 2 & Model 3 & Model 4 \\
\hline Human Integration Speed & & -.002 & .007 & .002 \\
Functional Integration Speed & & $.166^{*}$ & $.169^{*}$ & $.137+$ \\
Labor Market Flexibility & & & $-.175+$ & $-.333^{* *}$ \\
Labor Market Efficiency & & & .034 & $.285^{*}$ \\
Labor Market Flexibility x Human Integration Speed & & & & $.188+$ \\
Labor Market Flexibility x Functional Integration Speed & & & & $-.213^{*}$ \\
Labor Market Efficiency x Human Integration Speed & & & & $-.318^{* *}$ \\
Labor Market Efficiency x Functional Integration Speed & & & & $.361^{* *}$ \\
Relative Size & .005 & .029 & .035 & .045 \\
Annual Sales & .050 & .060 & .023 & .018 \\
Industry Growth & $.189 *$ & $.180^{*}$ & $.183^{*}$ & $.148+$ \\
Acquisition Experience & .050 & .036 & .060 & .062 \\
Transaction Type & $.142^{*}$ & $.145^{*}$ & $.129+$ & $.127+$ \\
Merger Acquisition & -.017 & -.0066 & -.011 & .001 \\
Competition Intensity Differences & -.045 & -.038 & -.038 & -.094 \\
Average Growth & .089 & .082 & .093 & .095 \\
\hline F-Value & 2.395 & 2.527 & 2.531 & 2.588 \\
Adjusted R ${ }^{2}$ & .052 & .070 & .083 & .112 \\
\hline
\end{tabular}

$+\mathrm{p}<.1{ }^{*} \mathrm{p}<.05 ; * * \mathrm{p}<.01 ;$ two-tailed tests 
Figure 1: The moderating impact of labor market flexibility on the human integration speed performance relationship

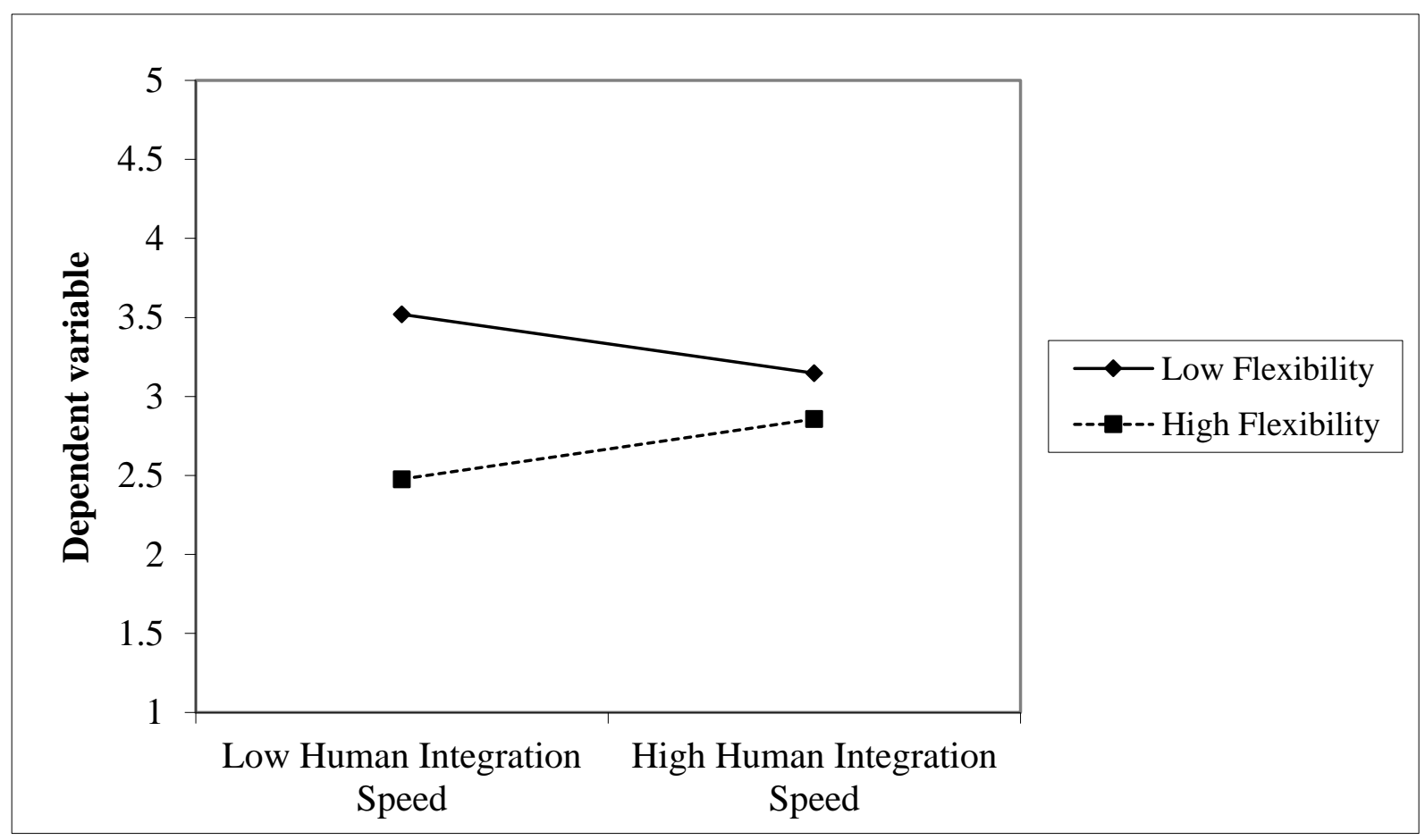


Figure 2: The moderating impact of labor market flexibility on the functional integration speed performance relationship

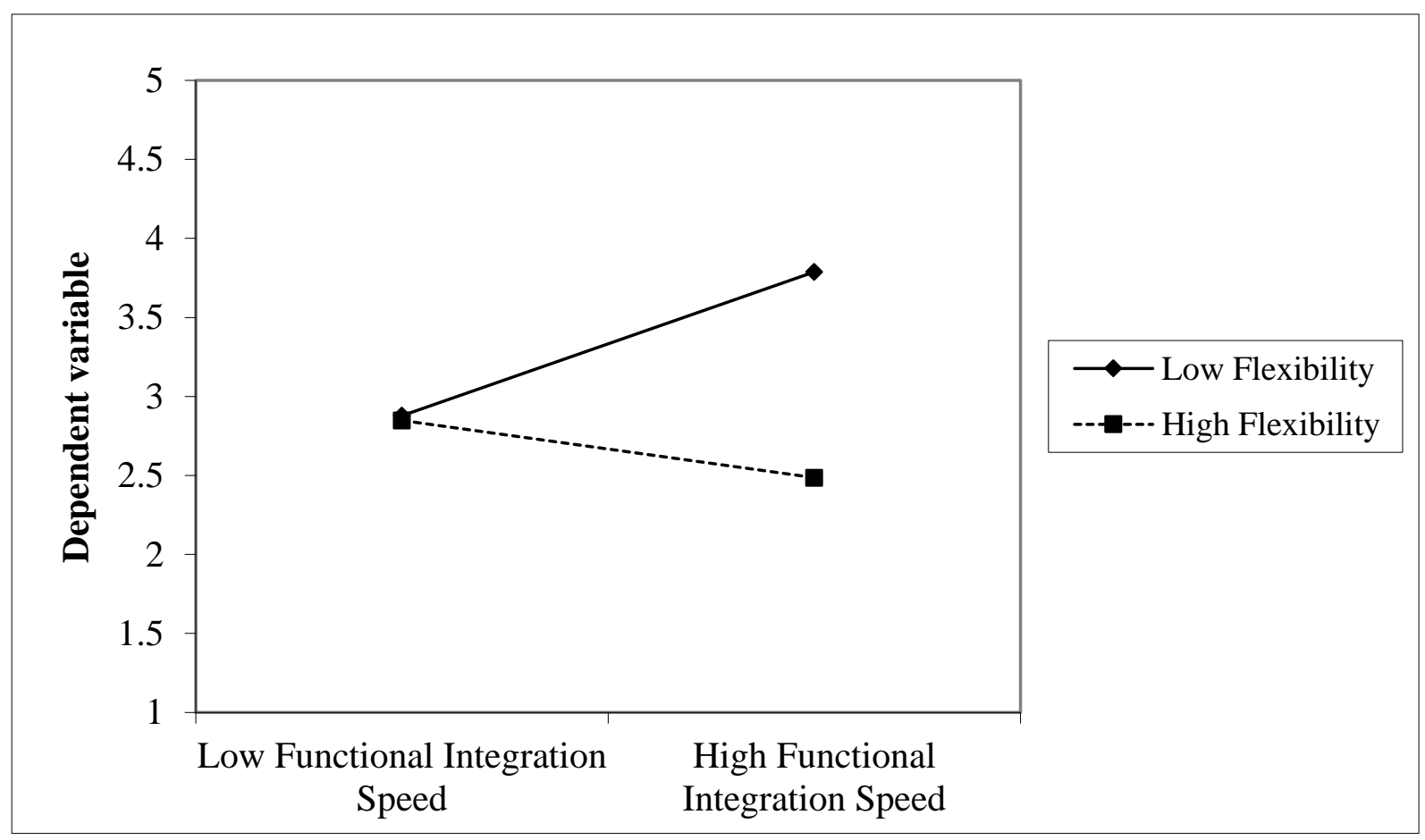


Figure 3: The moderating impact of labor market efficiency on the human integration speed performance relationship

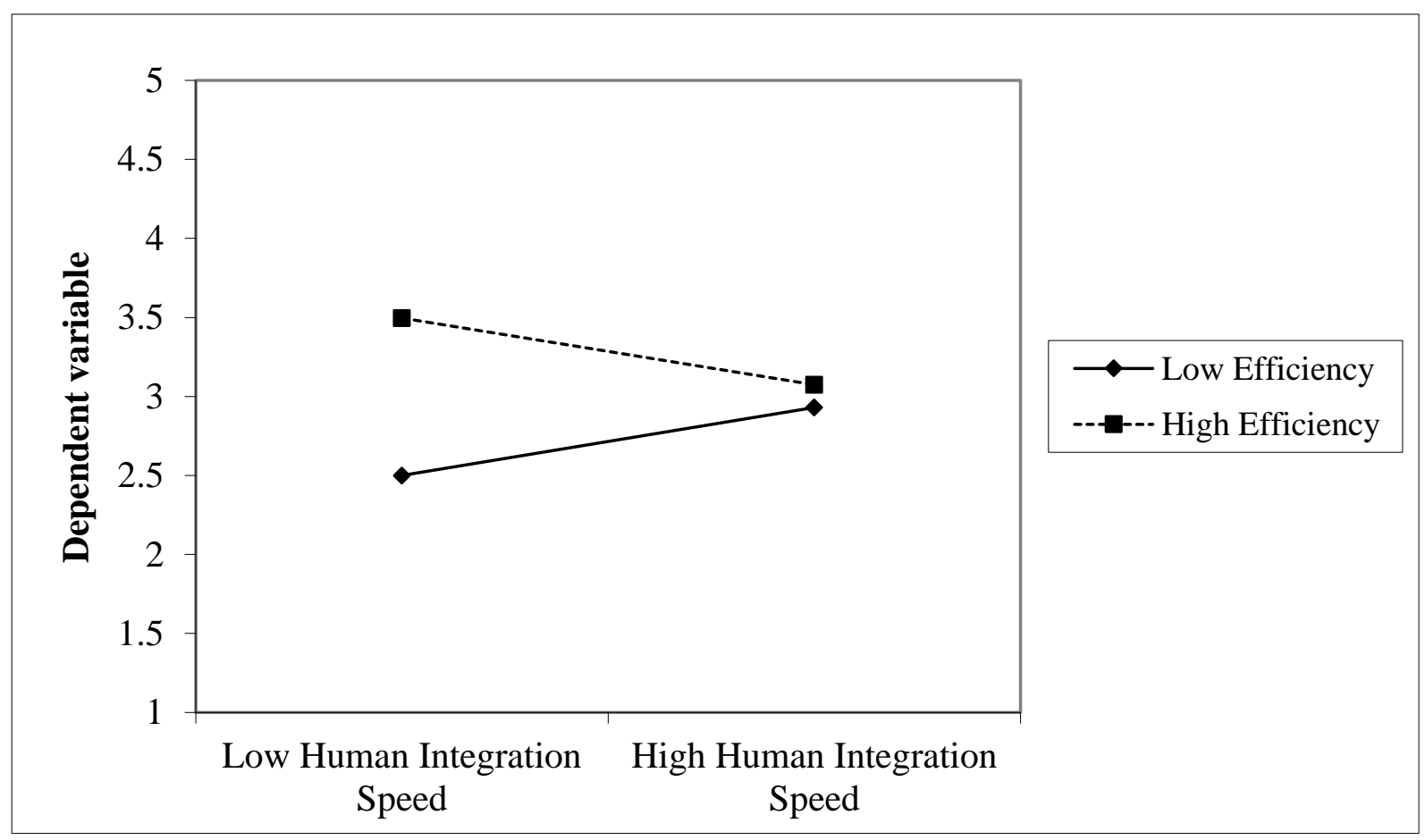


Figure 4: The moderating impact of labor market efficiency on the functional integration speed performance relationship

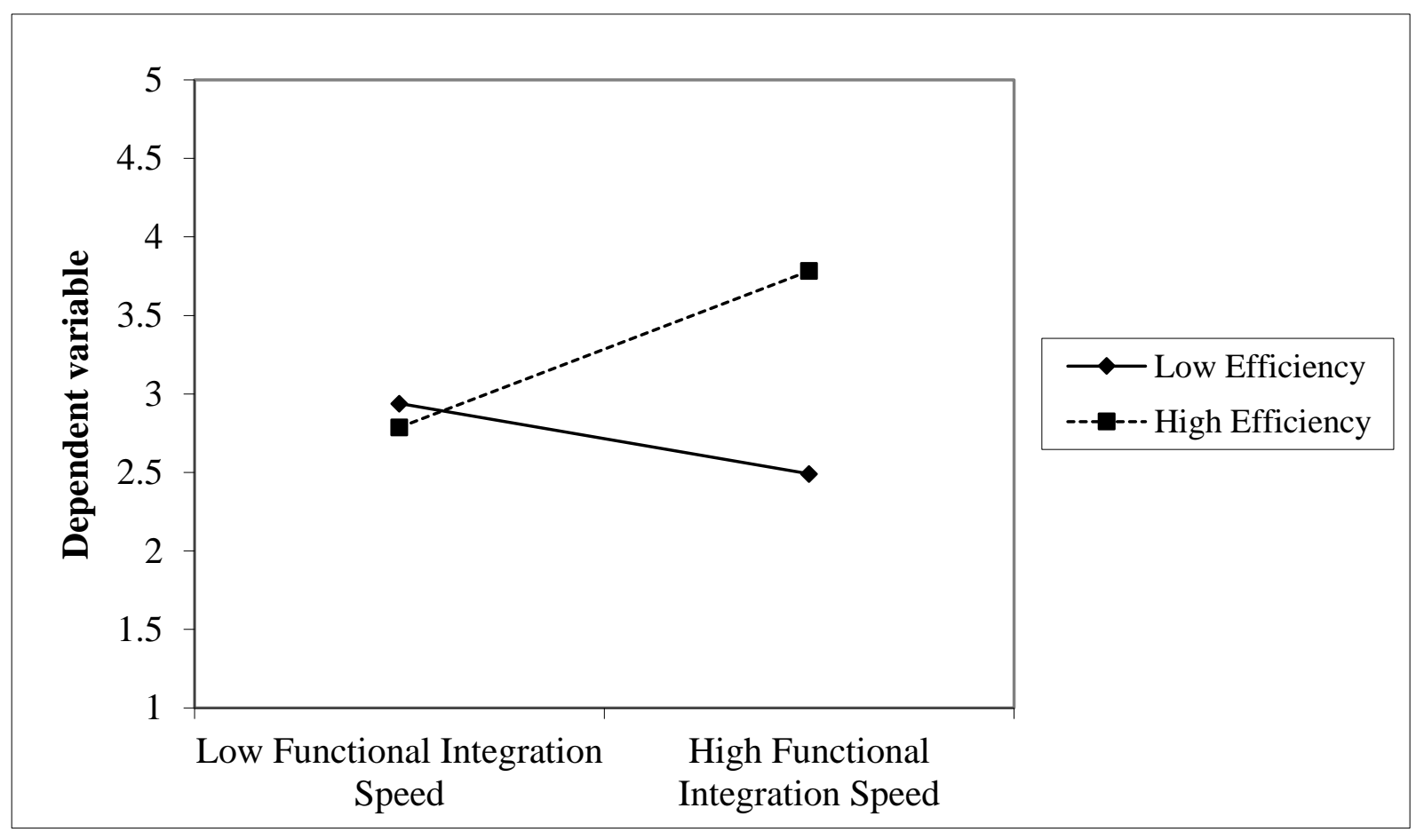

